\title{
The diversity of endophytic fungi in the above-ground tissue of two Lycopodium species in Poland
}

\author{
Julia Pawłowska • Mateusz Wilk • Anna Śliwińska-Wyrzychowska • \\ Monika Mętrak • Marta Wrzosek
}

Received: 2 July 2013 / Accepted: 15 August 2014 / Published online: 10 September 2014

(C) The Author(s) 2014. This article is published with open access at Springerlink.com

\begin{abstract}
Endophytes are a large and diverse group of fungi that colonize healthy plant tissues without causing any symptoms. The majority of studies have focused on angiosperm and conifer hosts and few have examined the endophytes of lycophytes. In the present study, we characterized culturable endophytic fungi in two closely related Lycopodium species (L. annotinum and L. clavatum) from pine, beech, oak and spruce forests across Poland. More than 400 strains were isolated but only 18 Ascomycete species were identified. Members of the Dothideomycetes dominated the fungal endophyte communities in Lycopodium. The most abundant taxa cultured were Phoma brasiliensis (from L. clavatum) and Paraconiothyrium lycopodinum (from L. annotinum). Five
\end{abstract}

Electronic supplementary material The online version of this article (doi:10.1007/s13199-014-0291-1) contains supplementary material, which is available to authorized users.

J. Pawłowska $(\bowtie) \cdot$ M. Wrzosek

Department of Systematics and Plant Geography, Faculty of Biology,

The University of Warsaw, Al. Ujazdowskie 4, 00-478 Warsaw,

Poland

e-mail: jzpawlowska@gmail.com

J. Pawłowska

e-mail: julia.pawlowska@biol.uw.edu.pl

M. Wilk

College of Inter-Faculty Individual Studies in Mathematics and Natural Sciences, The University of Warsaw, Żwirki i Wigury 93, 02-089 Warsaw, Poland

\section{A. Śliwińska-Wyrzychowska}

Department of Botany and Plant Ecology, Institute of Chemistry, Environmental Protection and Biotechnology, Jan Długosz University in Częstochowa, Al. Armii Krajowej 13/15,

42-201 Częstochowa, Poland

M. Mętrak

Department of Plant Ecology and Environmental Protection, The University of Warsaw, Al. Ujazdowskie 4, 00-478 Warsaw, Poland taxa were isolated exclusively from $L$. annotinum, but only two of them (Paraconiothyrium lycopodinum and Mycosphaerella sp.) were relatively abundant. Two taxa were only found in L. clavatum, namely: Stagonospora pseudovitensis and an unidentified Dothideomycete. The taxon assigned as Ascomycota 2 (SH219457.06FU) was isolated only from strobili of both host species. Direct PCR and cloning from $L$. annotinum shoots revealed a substantially greater endophyte richness compared with the results from culturing.

Keywords Lycophyte $\cdot$ Endophyte $\cdot$ Fungi $\cdot$ Diversity

\section{Introduction}

Lycopodium (Lycopodiaceae, Lycopodiophyta, Plantae) is a genus of flowerless, vascular, terrestrial plants that reproduce sexually via homospores, and vegetatively from rhizomes. The Lycopod lineage diversified early and was the dominant vegetation in Carboniferous period (Ranker and Haufler 2008). Reports of fossils found in the Rhynie chert suggest that arbuscular mycorrhizal fungi and Lycopods co-evolved from the beginning (Remy et al. 1994; Taylor et al. 1999, 2004).

Endophytes form a large and phylogenetically diverse group of fungi that colonize healthy plant tissues without causing symptoms (Wilson 1995). Endophytes sensu stricto differ from mycorrhizal fungi by the fact that they reside entirely within plant tissues (Stone et al. 2004). Four classes of endophytes have been distinguished: 1) the clavicipitaceous endophytes, 2) the nonclavicipitaceous endophytes that colonize the whole plant, 3) the nonclavicipitaceous endophytes that colonize shoots, and 4) the nonclavicipitaceous endophytes that colonize roots (Rodriguez et al. 2009). All land plants studied to date, including lycophytes, are colonized by class three endophytes which are horizontally transmitted (Davis et al. 2003; Saikkonen et al. 1998). The representatives of this class occur in above-ground 
tissues, form localized infections and are remarkable for their high diversity even within individual hosts (e.g. Arnold 2007; Higgins et al. 2007). Many studies have tried to determine whether endophytes exhibit tissue- and host-specificity but the results are contradictory (Arnold et al. 2001; Higgins et al. 2007, 2011; Joshee et al. 2009; Moricca et al. 2012; Sun et al. 2012; Wearn et al. 2012), with indications of both host-specificity and hostgeneralism (see review of older reports by Zhou and Hyde (2001).

Only few studies have been devoted to examining the endophytic community of Lycopodiaceae (e.g. Budziszewska and Szypuła 2010; Chen et al. 2011; Wang et al. 2011), and two have been driven by an interest in identifying possible novel bioactive chemical compounds (e.g. Zhu et al. 2010; Xiang et al. 2013). Indeed, some endophytic fungi from lycophyte Huperzia serrata that is used in chinese medicine are known to produce bioactive metabolites such as huaspenones, (Xiang et al. 2013) or huperzine (see Zhu et al. 2010; Zhang et al. 2011, and literature therein). Only two studies, by Holm and Holm (1981) and by Engelhardt (1987), have been dedicated studying the fungal communities of above-ground organs of Lycopodiaceae.

Representatives of the Lycopodiaceae have been included in broader comparative studies of fungal endophytic communities in different plant groups (e.g. Higgins et al. 2007; U'Ren et al. 2012). Although the Lycopodiaceae have been studied for over 100 years, most researches have focused on the symbiotic relationships between the prothalli and mycorrhizal fungi (e.g. Bruchmann 1908; Freeberg 1962; Whittier 1977; Berch and Kendrick 1982; Schmid and Oberwinkler 1993; Read et al. 2000; Lee et al. 2001; Wang and Qiu 2006; Leake et al. 2008; Kessler et al. 2010a, b; Muthukumar and Prabha 2013). Even in this respect, only about 17 species of Lycopodiaceae have been studied (Wang and Qiu 2006). Non-mycorrhizal fungi (e.g. pathogens or saprotrophs) from Lycopodiaceae have also been examined in surveys (e.g. Hagen 1950; Holm and Holm 1984; Jaklitsch and Voglmayr 2012) or when preparing monographs of particular genera (e.g. Massarina by Aptroot 1998 or Phaeosphaeria by Leuchtmann 1984).

The aim of the present study was to characterize the fungal endophytic communities of two closely related Lycopodium species. We addressed the following questions: 1) How diverse are endophytic fungi from Lycopodium in temperate forest? 2) Is species community composition influenced by host plant, plant organ, geographic location of the host, or host habitat characteristics? 3) What is the taxonomic identity of hypothetical species isolated as endophytes?

\section{Materials and methods}

\subsection{Host plant collection and localization of sampling sites}

Shoots ( 8 individuals), strobili (15 individuals) and whole plants (shoots and strobili from the same individual; 13 individuals) of $L$. annotinum from 36 sites, and 10 shoots, 15 strobili, 2 whole plants (shoots and strobili from the same individual) of $L$. clavatum from 27 locations from temperate forests in Poland were collected (a total of 63 locations, 63 individuals and 78 samples; Fig. 1; see supplementary table S1). Sampling sites differed in terms of vegetation, with majority located in pine forests ( 27 sites); others in mixed forests (12 sites), acidophilic beech forests (1 site), acidophilic oak forests (4 sites), bog pine forests (11 sites), or mountain spruce forests ( 8 sites). Samples were further characterized by site elevation: lowlands (6 sites, 10 samples), highlands (49 sites, 58 samples), and mountains ( 8 sites, 10 samples; see supplementary table S1). Samples were collected in summer and autumn 2011 (see supplementary table S1). Each specimen was wrapped in a paper towel moistened with sterile water and placed in sterile plastic tube for transportation to the laboratory.

\subsection{Endophytes isolation and identification}

Healthy shoots and strobili of $L$. annotinum and $L$. clavatum were washed in tap water and surface-sterilized by subsequent submersion of the plant tissue for $2 \mathrm{~min}$ in a $0.5 \%$ sodium hypochlorite and for $2 \mathrm{~min}$ in $70 \%$ ethanol. Finally, samples were rinse in sterile distilled water, as described by Davis et al. (2003). This method eliminates epiphytic bacteria, yeasts, and fast-growing Zygomycetes (Arnold et al. 2000). The absence of epiphytic fungi was then verified by imprinting sterilized plant fragments on control PDA plates (if no fungal growth was observed, the plant fragment was considered to have been effectively surface-sterilized). Subsequently, the samples of lycophytes were cut in $2 \mathrm{~mm}$ pieces. Eight segments per organ (shoot or strobili) per site were plated (624 segments in total) on $4 \%$ potato dextrose agar (PDA; without antibiotics). All plates (control and samples) were incubated at room temperature $\left(\mathrm{ca} .18^{\circ} \mathrm{C}\right.$ ) for 10 weeks or until fungal growth was observed. Using aseptic technique, emergent hyphae were transferred and purified on sterile PDA plates. The endophytes were grouped into morphotypes as described by Wang et al. (2011). Identification of the isolated strains was done using Domsch et al. (1993), Samson et al. (2004), and Watanabe (2002). Ninety six morphotypes were distinguished.

Genomic DNA was extracted from pure cultures of a representative isolate of each fungal morphotype using the GeneMATRIX Plant \& Fungi DNA Purification Kit (EURx Ltd., Gdańsk, Poland) following the manufacturer's instructions. The complete ITS region was amplified using the primer pair ITS1f and ITS4 (White et al. 1990). PCR products were analyzed on a $1 \%$ agarose gel stained with $\mathrm{EtBr}$, and positive amplicons were purified using the GeneMATRIX AgaroseOut DNA Purification Kit (EURx Ltd). Purified DNA fragments were sequenced in both directions using the BigDye ${ }^{\circledR}$ Terminator v3.1 Cycle Sequencing Kit (Applied Biosystems, 
Fig. 1 Distribution of sample sites

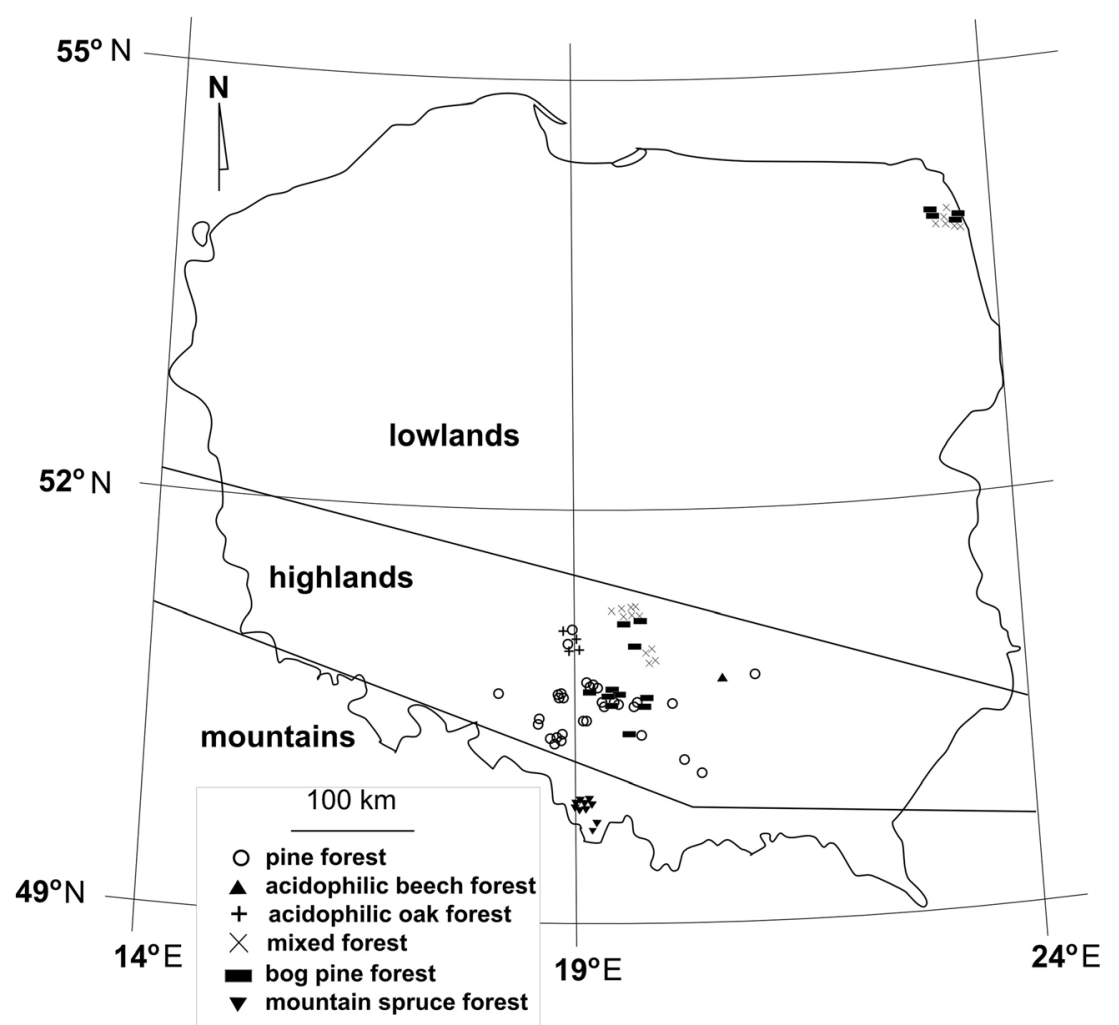

Carlsbad, CA, USA). Sequencing was performed at the Institute of Biochemistry and Biophysics, the Polish Academy of Sciences. Forward and reversed sequences were aligned into contigs and manually edited for errors using the BioEdit Sequence Alignment Editor v. 7.0.0 (Hall 1999).

ITS sequences of all (96) morphotypes were grouped into operational taxonomic units (OTUs) according to $98.5 \%$ similarity using BioEdit Sequence Alignment Editor v. 7.0.0 (Hall 1999). This $98.5 \%$ cutoff was selected and used for the hypothetical species assignment in the UNITE database (Kõljalg et al. 2013).

In order to estimate the fraction of unculturable endophytes, total genomic DNA was extracted (as described above) from sterilized L. annotinum shoot from site no. 30 (coordinates in supplement S1). The ITS and 5.8S rDNA regions were amplified using fungal specific primer pair ITS1-f and ITS4 (as described above). PCR products were ligated into pGEM-T Easy Vector (Promega, Leiden, The Netherlands) and cloned in E. coli JM109 competent cells (Promega) following the manufacturer's instructions. Colony PCRs were performed using universal primer pair M13f and M13r.

Representative vouchers specimens for each OTU were deposited at the General Herbarium, University of Warsaw. Their numbers as well as the GenBank accession numbers of their sequences are presented in Table 1.

\subsection{Data analysis}

ITS sequences representing each morphotype were queried against the UNITE database using the massBLAST algorithm (http://unite.ut.ee; Abarenkov et al. 2010; Kõjalg et al. 2005). Species Hypothesis (SH) at $98.5 \%$ of sequence similarity were used to identify isolated morphotypes (Kõljalg et al. 2013). If SH at $98.5 \%$ of similarity was not proposed, the results of BLASTn (Altschul et al. 1997) searches were used to estimate taxonomic position of isolate and then detailed explanation concerning each case were given in Table 1.

The colonization factor $(\mathrm{CF} \%$; called also isolation frequency or colonization frequency) was calculated as the total number of plant segments colonized by fungi divided by the total number of all incubated segments, expressed as its percentage (Hata and Futai 1995). Relative abundance was calculated as the number of all isolates of a given taxon divided by the total number of isolates of all taxa. Frequency was calculated as the number of host individuals of fungal taxon isolated divided by the total number of all host individuals (Sun et al. 2012). Species diversity was evaluated using Shannon's Diversity Index (Shannon 1948) and Fisher's alpha (Fisher et al. 1943). The species evenness was estimated with Pielou's evenness index (Pielou 1966). The similarity of endophytic communities between different sampling sites (63) was evaluated using the Jaccard similarity coefficient (Jaccard 1912). Sample-based species accumulation curves for 
Table 1 Hypothetical species assignment of isolated strains based on massBLAST queries in UNITE database (for ITS sequences at $98.5 \%$ of similarities). If the taxon assignment was done in different way than it is explained in footnotes. Isolates are presented in table according to their higher level classification (classes and orders)

\begin{tabular}{|c|c|c|c|c|}
\hline Species hypotheses $(\mathrm{SH})$ name & SH number & $\begin{array}{l}\text { Voucher herbarium } \\
\text { number }\end{array}$ & $\begin{array}{l}\text { GenBank accession } \\
\text { number }\end{array}$ & $\begin{array}{l}\text { Taxon name used further in this } \\
\text { paper }\end{array}$ \\
\hline \multicolumn{5}{|l|}{ Dothideomycetes } \\
\hline \multicolumn{5}{|l|}{ Capnodiales } \\
\hline $\begin{array}{l}\text { Davidiella tassiana (syn. Mycosphaerella } \\
\text { tassiana) }\end{array}$ & SH196750.06FU & WA19047 & JX981454 & Mycosphaerella tassiana \\
\hline $\begin{array}{l}\text { Mycosphaerella sp. } \\
\text { Dothideales }\end{array}$ & \multicolumn{3}{|c|}{ Dothideales } & Mycosphaerella sp. \\
\hline $\begin{array}{l}\text { Aureobasidium pullulans } \\
\text { Pleosporales }\end{array}$ & \multicolumn{3}{|c|}{ Pleosporales } & Aureobasidium pullulans \\
\hline Ascomycota & SH224125.06FU & WA19030 & JX629111 & Ascomycota 1 \\
\hline Dothideomycetes & SH196053.06FU & WA19143 & JX981466 & Dothideomycetes \\
\hline Phoma brasiliensis & SH202145.06FU & WA19053 & JX981489 & Phoma brasiliensis \\
\hline Pleosporales & SH233951.06FU & WA19052 & JX981474 & Pleosporales \\
\hline Pyrenophora chaetomioides & SH227032.06FU & WA19141 & JX981468 & Pyrenophora chaetomioides \\
\hline Stagonospora pseudovitensis & SH199974.06FU & WA19138 & JX981472 & Stagonospora pseudovitensis \\
\hline no $\mathrm{SH}$ proposed ${ }^{\mathrm{a}}$ & & WA19040 & JX981452 & 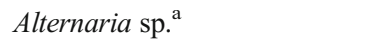 \\
\hline no SH proposed ${ }^{\mathrm{b}}$ & & WA19015 & JX629096 & Paraconiothyrium lycopodinum ${ }^{\mathrm{b}}$ \\
\hline no SH proposed ${ }^{\mathrm{c}}$ & & WA19023 & JX629104 & Paraconiothyrium polonense $e^{\mathrm{c}}$ \\
\hline no SH proposed ${ }^{\mathrm{d}}$ & & WA19031 & JX629112 & Paraphaeosphaeria sp. ${ }^{\mathrm{d}}$ \\
\hline \multicolumn{5}{|l|}{ Leotiomycetes } \\
\hline \multicolumn{5}{|l|}{ Helotiales } \\
\hline Helotiales & SH232201.06FU & WA19148 & JX981467 & Helotiales \\
\hline Phacidium lacerum & SH108595.06FU & WA19039 & JX981469 & Phacidium lacerum \\
\hline \multicolumn{5}{|l|}{ Sordariomycetes } \\
\hline \multicolumn{5}{|l|}{ Hypocreales } \\
\hline Ascomycota & SH219457.06FU & WA19121 & JX981457 & Ascomycota 2 \\
\hline $\begin{array}{l}\text { Trichoderma viride (syn. Hypocrea rufa) } \\
\quad \text { Xylariales }\end{array}$ & SH222750.06FU & WA19150 & JX981461 & Trichoderma viride \\
\hline Leiosphaerella lycopodina & SH230356.06FU & WA19125 & JX981475 & Leiosphaerella lycopodina \\
\hline
\end{tabular}

${ }^{\mathrm{a}}$ The closest sequences in blast queries are: Alternaria tenuissima (KJ082100; $100 \%$ similarity) and Alternaria alternata (KJ082099; $100 \%$ similarity) thus the strain is identified as Alternaria sp.

${ }^{\mathrm{b}}$ The strain was identified by authors based on morphology and was described recently as new species Paraconiothyrium lycopodinum (Sacc. \& Paol.) J. Pawłowska, Wilk, Śliwińska-Wyrzychowska, Mętrak \& Wrzosek (Crous et al. 2013)

${ }^{\mathrm{c}}$ The strain was identified by authors based on morphology and was described recently as new species Paraconiothyrium polonense J. Pawłowska, Wilk, Śliwińska-Wyrzychowska, Mẹtrak \& Wrzosek (Crous et al. 2013)

${ }^{\mathrm{d}}$ The closest sequences in blast queries are: Paraphaeosphaeria sporulosa (JX629112; $100 \%$ similarity) and Paraphaeosphaeria neglecta (JX496204; $100 \%$ similarity) thus the species is identified as Paraphaeosphaeria sp.

different hosts and organs were calculated and estimations of total richness were compared using the Jackknife 1 extrapolation algorithm. To correct for unequal sample sizes, the data was reduced to the smallest, consistent sample size $(N=12$, for shoots of Lycopodium clavatum). All indices were calculated using EstimateS v.9.1.0. (Colwell 2006).

Statistical analyses were then performed in four different variants in order to compare the influence of host plant, type of plant organ, host geographical location, and host habitat characteristics: (1) comparison between Lycopodium calavatum and Lycopodium annotinum; (2) comparison between shoots and strobili; (3) comparison between the samples coming from lowlands, highlands and mountains; (4) comparison between the samples collected from mixed pine, fresh pine, acidophilic oak, mountain spruce, pine bog, and acidophilic beech forests. To correct for inconsistent sample sizes in diversity and richness comparisons between samples, the data was 
reduced to the smallest sample size (randomly selected host individuals) as proposed by Davis and Shaw (2008).

In all the described variants, after the performance of the Shapiro-Wilk tests for normality for each variant separately, Kruskal-Wallis one-way analysis of variance was chosen as an appropriate method of comparison (non-parametric test for groups of unequal size) (Kruskal and Wallis 1952).

Variation in community composition was examined as a function of host, organ, location and vegetation type using three different ecological community similarity measures: Jaccard's similarity index, the Bray-Curtis coefficient and Euclidean distance. Resulting matrices were represented using non-metric multidimensional scale (NMDS) plots. To avoid pseudoreplication, data from different tissues types of the same host individual were pooled for NMDS analyses that examine the effect of host, location, and vegetation type. The Kruskal's stress was used to decide which grouping of data is the most accurate (commonly acceptable when lower than 0.2) (Ek-Ramos et al. 2013).
Additionally, the correlation between Jaccard similarity coefficient and geographic distance was tested for significance using simple Mantel test. The geographical distances (in km) based on coordinates of collection sites (WGS84 system) were determined using own program written in $\mathrm{C}$ (assuming that the earth is a perfect sphere and its radius is $6,378 \mathrm{~km}$ ).

All statistical analyses were calculated using STATISTICA v. 10 and PAST v. 2.16 software (Hammer et al. 2001).

\section{Results}

From 624 Lycopodium segments (representing a total of 63 locations, 63 individuals and 78 samples), a total of 458 isolates, representing 96 morphotypes, 18 OTUs (hypothetical species defined in UNITE database) (Table 1), which belong only to the Ascomycota, were isolated during this study. Representatives of Dothideomycetes were isolated the most frequently. However,
Fig. 2 a Species accumulation curve for analyzed host species and organs. b Jackknife 1 total richness estimator curve. Sample sizes were standardized to the smallest consistent size $(N=12$, from shoots of Lycopodium clavatum)
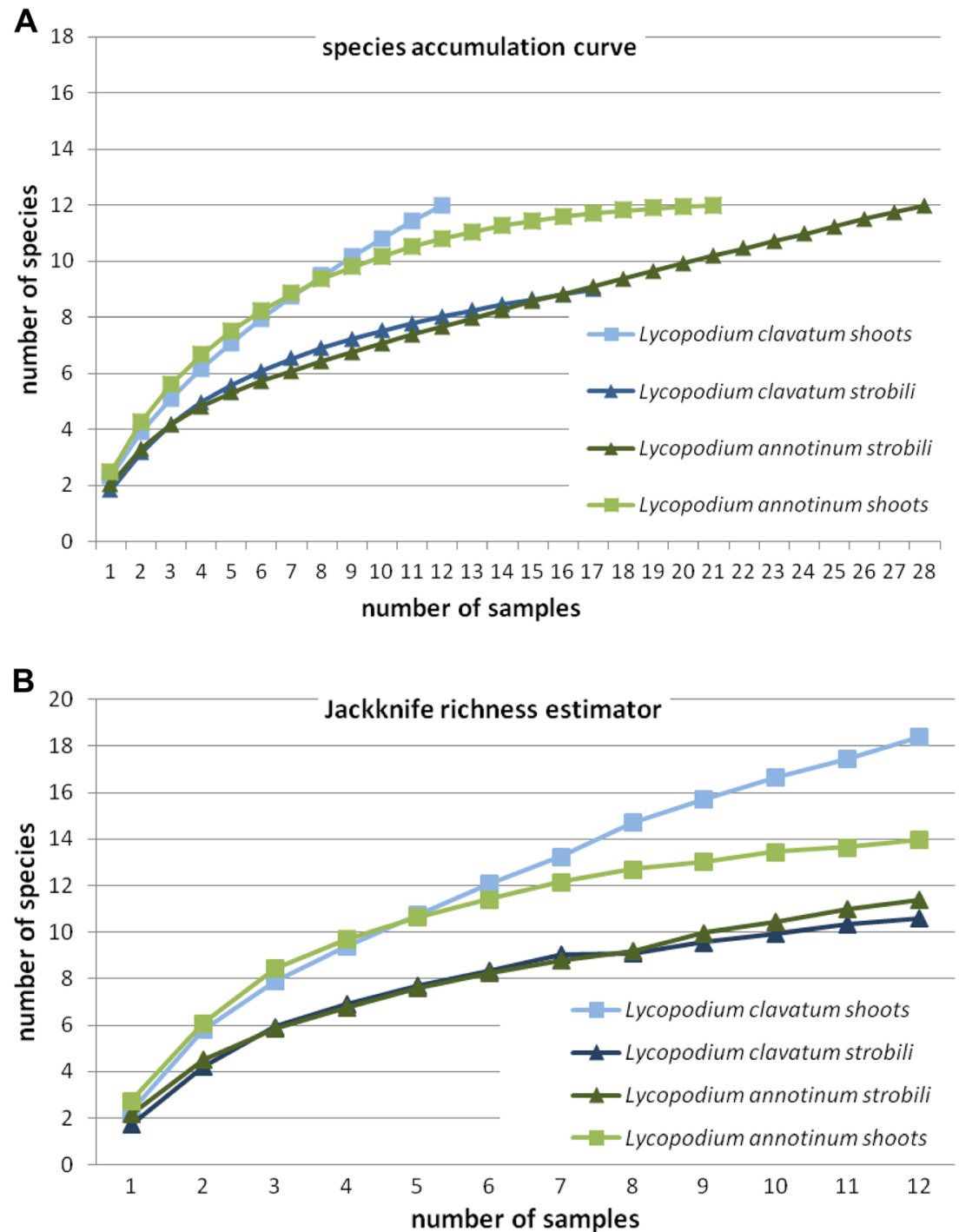
only in the case of $L$. annotinum shoots did the accumulation curve reach an asymptote. The Jacknife richness estimator did not reach an asymptote which indicates that richness would continue to increase with further sampling (Fig. 2). The most abundant taxa were Phoma brasiliense in L. clavatum and Paraconiothyrium lycopodinum in L. annotinum (Table 2). The highest frequency was observed also for these two taxa (Fig. 3).

None of the isolated taxa was present in all samples. There were 5 taxa isolated exclusively from $L$. annotinum, but only two of them (Paraconiothyrium lycopodinum and Mycosphaerella sp.) were relatively abundant (more than 5 isolates). There were also two taxa that were exclusive for L. clavatum, namely: Stagonospora pseudovitensis and unidentified Dothideomycetes (SH196053.06FU). The taxon assigned as Ascomycota 2 (SH219457.06FU) was isolated only from strobili of both host species.

Although we analyzed many more segments of $L$. annotinum than L. clavatum, the number of isolated species as well as colonization factor and values of species diversity indices for random 12 samples (the smallest sample size) were very similar (Table 3 ).

There were no significant differences in total number of fungal species $(p=0.1872)$, total number of isolates $(p=$ $0.1455)$, colonization factor $(p=0.1455)$, Shannon diversity $(p=0.2263)$, Fisher's alpha $(p=0.0953)$ and evenness $(p=$ 0.2206 ) between the two Lycopodium species.

The total number of fungal species $(p=0.1623)$, total number of isolates $(p=0.8355)$, colonization factor $(p=0.8355)$, Shannon diversity ( $p=0.1073)$, Fisher's alpha $(p=0.8020)$ and evenness ( $p=0.1305$ ) between different site locations (mountain, highland, lowland) and vegetation type of sample site (mixed, pine, oak, mountain spruce, pine bog, or beech forests) (p values: $0.2438,0.1183,0.1183,0.1947,0.5178$, 0.6572 respectively) also did not statistically differ.

Only the Shannon diversity index $(p=0.0294)$ was significantly higher in shoots than in strobili for both Lycopodium species (see also Table 3). This pattern is also visible in species accumulation and in Jacknife 1 richness estimator curves (Fig. 2).

Cluster analysis of endophytic community similarity measures presented in two-dimensional NMDS plots revealed that these communities are neither lycophyte-host-related, nor organ-related (even though differences is diversity between organs are significant). Variation in endophytic community structure could neither be explained by site vegetation type nor by geographic region of host plant origin (Fig. 4). The use of different ecological similarity measures did not significantly affect the observed patterns (data not shown). In most cases Kruskal's stress values were too high $(>0.2)$ to confidently discern any pattern. However, the two samples of L. annotinum from the lowland that had a very different endophytic communy from samples collected from other elevations.

The shoots of L. annotinum from site 30 (as described in supplement S1) on PDA medium yielded only two species Leiosphaerella lycopodina and Mycosphaerella sp., while in the cloning experiment with the plant tissue, seven different sequences were obtained (Table 4). The sequences of both
Table 2 Relative abundance (\%) of endophytic fungi isolated from shoots and strobili of two Lycopodium species (the most abundant taxa for each host are shown in bold)

\begin{tabular}{|c|c|c|c|c|c|c|}
\hline & \multicolumn{3}{|c|}{ Lycopodium clavatum } & \multicolumn{3}{|c|}{ Lycopodium annotinum } \\
\hline & Shoots & Strobili & Total & Shoots & Strobili & Total \\
\hline Alternaria sp. & 2.38 & 1.52 & 3.90 & 2.38 & 3.25 & 5.63 \\
\hline Ascomycota 1 & 0.65 & 0.00 & 0.65 & 0.00 & 0.22 & 0.22 \\
\hline Ascomycota 2 & 0.00 & 3.25 & 3.25 & 0.00 & 6.06 & 6.06 \\
\hline Aureobasidium pullulans & 0.00 & 0.00 & 0.00 & 0.00 & 0.43 & 0.43 \\
\hline Dothideomycetes & 0.00 & 1.08 & 1.08 & 0.00 & 0.00 & 0.00 \\
\hline Helotiales & 0.00 & 0.00 & 0.00 & 0.87 & 0.43 & 1.30 \\
\hline Leiosphaerella lycopodina & 0.00 & 0.00 & 0.00 & 0.87 & 0.00 & 0.87 \\
\hline Mycosphaerella sp. & 0.00 & 0.00 & 0.00 & 2.16 & 0.43 & 2.60 \\
\hline Mycosphaerella tassiana & 1.95 & 0.65 & 2.60 & 1.95 & 0.43 & 2.38 \\
\hline Paraconiothyrium lycopodinum & 0.00 & 0.00 & 0.00 & 6.93 & 14.29 & 21.21 \\
\hline Paraconiothyrium polonense & 2.60 & 2.38 & 4.98 & 1.73 & 1.52 & 3.25 \\
\hline Paraphaeosphaeria sp. & 0.87 & 0.00 & 0.87 & 0.65 & 0.00 & 0.65 \\
\hline Phacidium lacerum & 0.43 & 0.00 & 0.43 & 0.87 & 0.22 & 1.08 \\
\hline Phoma brasiliensis & 4.55 & 7.36 & 11.9 & 6.49 & 9.09 & 15.58 \\
\hline Pleosporales & 0.22 & 0.22 & 0.43 & 0.43 & 0.00 & 0.43 \\
\hline Pyrenophora chaetomioides & 0.22 & 0.00 & 0.22 & 1.08 & 0.43 & 1.52 \\
\hline Stagonospora pseudovitensis & 1.09 & 0.22 & 1.31 & 0.00 & 0.00 & 0.00 \\
\hline Trichoderma viride & 1.73 & 1.73 & 3.46 & 1.73 & 0.00 & 1.73 \\
\hline
\end{tabular}


Fig. 3 Frequency (\%; calculated for total of 78 individuals)' of the endophytic fungal isolates in shoots and strobili of the Lycopodium species

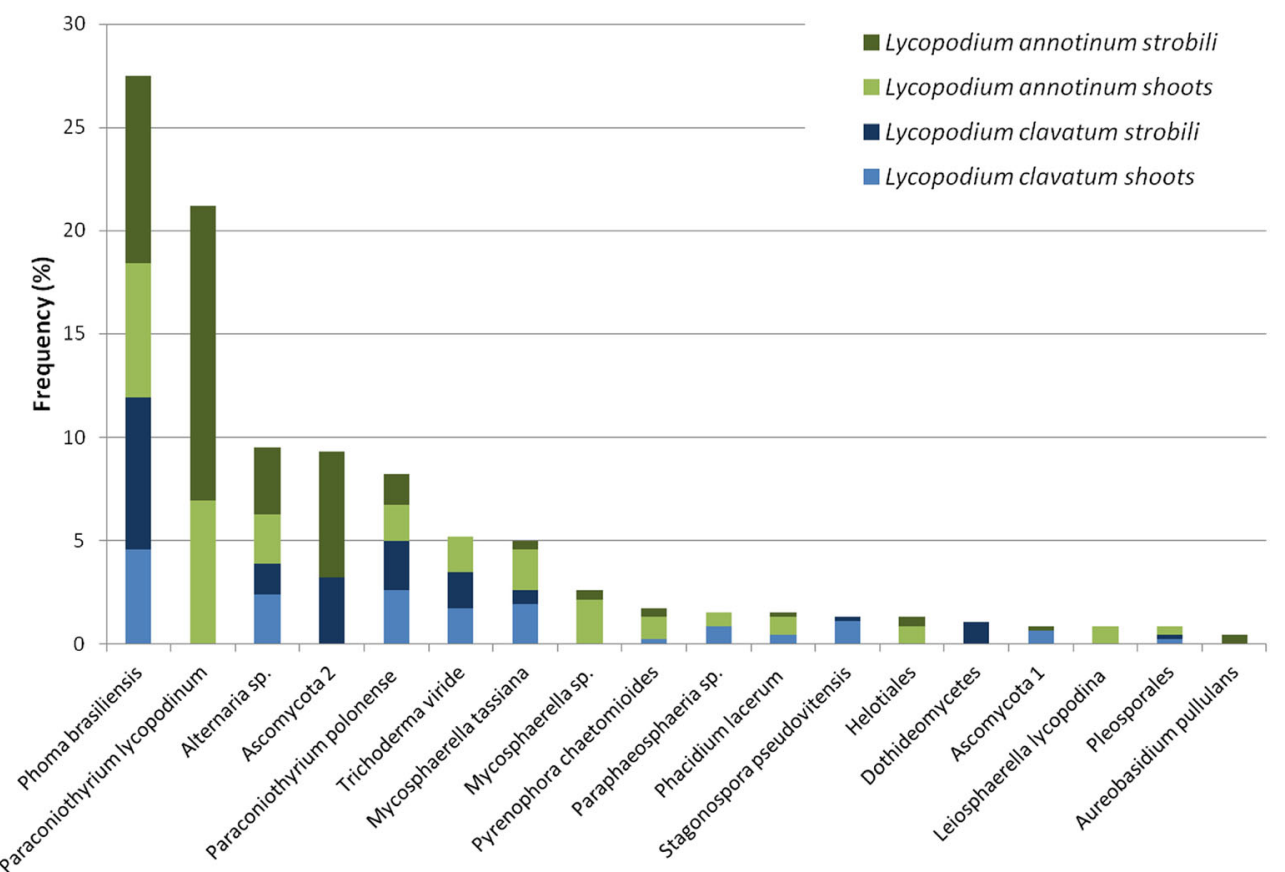

species isolated in culture were also present in cloned sequences and they were the most frequent ones. However, they still constituted less than a half of all obtained sequences.

\section{Discussion}

Higgins et al. (2007) found a low diversity of endophytes in Huperzia (Fisher's alpha 1.27-3.98) while U'Ren et al. (2012) found a very high diversity of endophytes in this genus in samples from Alaska (Fisher's alpha 15.64). These studies both used a culture-based approach for characterization of the fungal endophyte communities. This likely resulted in a serious underestimation of the fungal diversity. This is supported by our species accumulation curve (Fig. 2) as well as by the results of our cloning trial, where only less than half of all endophytic fungi present in the sample appeared in culture (Table 4). Another possibility is that species diversity may vary with environmental factors at sample sites but more study is required.

Among the isolated taxa, five were found exclusively in L. annotinum, of which only two (Paraconiothyrium lycopodinum and Mycosphaerella sp.) were abundant (more than 5 isolates). The isolate Ascomycota 2 (SH219457.06FU) was restricted to the strobili, regardless of the host species

Table 3 Overall colonization factor (\%), species richness, Shannon's diversity index, Fisher's alpha values and Pielou's evenness index of endophytic fungi isolated from shoots and strobili of two Lycopodium species

\begin{tabular}{|c|c|c|c|c|c|c|c|}
\hline & \multicolumn{3}{|c|}{ Lycopodium clavatum } & \multicolumn{4}{|c|}{ Lycopodium annotinum } \\
\hline & \multicolumn{2}{|l|}{ Strobili } & \multirow{2}{*}{$\begin{array}{l}\text { Shoots } \\
\text { Values for } \\
\text { all (12) } \\
\text { samples }\end{array}$} & \multicolumn{2}{|l|}{ Strobili } & \multicolumn{2}{|l|}{ Shoots } \\
\hline & $\begin{array}{l}\text { Values } \\
\text { for all } \\
\text { samples }\end{array}$ & $\begin{array}{l}\text { Values for } 12 \text { random } \\
\text { individuals (the smallest } \\
\text { sample size) }\end{array}$ & & $\begin{array}{l}\text { Values } \\
\text { for all } \\
\text { samples }\end{array}$ & $\begin{array}{l}\text { Values for } 12 \text { random } \\
\text { individuals (the smallest } \\
\text { sample size) }\end{array}$ & $\begin{array}{l}\text { Values } \\
\text { for all } \\
\text { samples }\end{array}$ & $\begin{array}{l}\text { Values for } 12 \text { random } \\
\text { individuals (the smallest } \\
\text { sample size) }\end{array}$ \\
\hline Number of host individuals & 17 & 12 & 12 & 28 & 12 & 21 & 12 \\
\hline Number of segments & 136 & 96 & 96 & 224 & 96 & 168 & 96 \\
\hline Total number of isolates & 85 & 60 & 77 & 167 & 72 & 129 & 74 \\
\hline Colonization factor $(\%)$ & 62.5 & 62.5 & 80.2 & 74.5 & 74.5 & 76.8 & 76.8 \\
\hline Total number of species & 9 & 8 & 12 & 12 & 8 & 12 & 11 \\
\hline Shanon's diversity index & 1.75 & 1.24 & 2.1 & 1.67 & 0.72 & 2.14 & 1.22 \\
\hline Fisher's alpha & 2.54 & 1.79 & 3.98 & 2.96 & 1.27 & 3.23 & 1.85 \\
\hline Pielou's evenness index & 0.796 & 0.596 & 0.845 & 0.672 & 0.803 & 0.861 & 0.892 \\
\hline
\end{tabular}


A

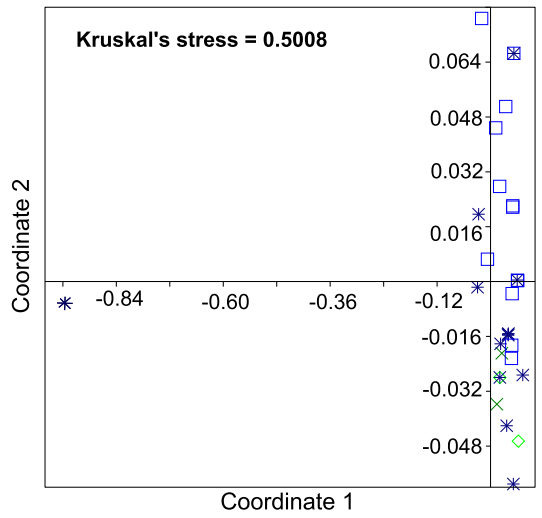

* Lycopodium annotinum shoot

$\square$ Lycopodium annotinum strobili

$\times$ Lycopodium clavatum shoot

Lycopodium clavatum strobili

Fig. 4 Non-metric multidimensional scale plots of Jaccard's similarity indexes representing effect of host, organ, location and vegetation type on fungal endophytic communities of Lycopodium annotinum and
B

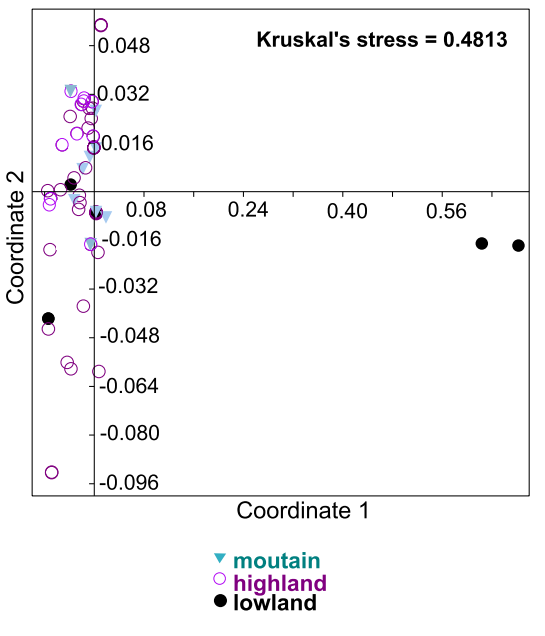

C

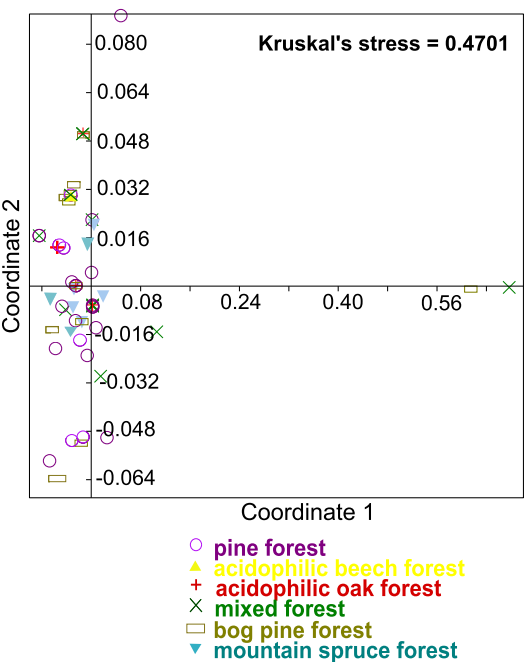

Lycopodium clavatum. Each point represents a single endophyte community from a particular individual (a for 15 whole plants, $\mathbf{b}$ and $\mathbf{c}$ for 63 individual each from different site). Kruskal's stress values are indicated

which suggests some level of tissue-preference, for this isolate. However, this might be a result of isolate rarity.

Cluster analysis of endophytic community similarity measures presented in two-dimensional NMDS plots revealed that only two samples from $L$. annotinum from lowland have very different endophytic community than all others. This pattern could be explained by the relatively high abundance of Mycosphaerella sp. and by the fact that both sites are relatively close together (240 m apart). As lycophytes can reproduce asexually, it is possible that the plants represent the same host individual. The abundant presence of Mycosphaerella sp. at these sites should be verified in further research.

Some of taxa isolated in our study are common and widespread saprotrophic fungi, e.g. Hypocrea rufa and its anamorph Trichoderma viride but they have been isolated as endophytes previously (Jaklitsch et al. 2006), but not from lycophytes. Among other taxa we isolated are well known plant pathogens, e.g. Leiosphaerella lycopodina that has been

recorded from Lycopodium annotinum several times (e.g. Jaklitsch and Voglmayr 2012) but never described to date as an endophyte.

One of the most abundant taxon in our study was Paraconiothyrium lycopodinum that could be identified as Coniothyrium lycopodinum Sacc. \& Paol. that was previously isolated as a possible pathogen from L. annotinum (Saccardo 1889). These two taxa were recently synonimized by Pawłowska et al. (in Crous et al. 2013) as Paraconiothyrium lycopodinum (Sacc. \& Paol.) J. Pawłowska, Wilk, ŚliwińskaWyrzychowska, Metrak \& Wrzosek, comb. nov. In spite of the fact that several Paraconiothyrium species have been isolated as endophytes from asymptomatic photosynthetic tissues of plant species (e.g. Abreu et al. 2010), including lycophytes (Budziszewska et al. 2011; Wang et al. 2011), in general they are still regarded as plant pathogens (Damm et al. 2008).

It is interesting that some fungi isolated in our study are known to be, or bear close affinities, to plant pathogens. This

Table 4 Comparison of SH proposed by UNITE for sequences that were received in culture based approach with ones from cloning experiment (from L. annotinum sample from site 30 in Puszcza Augustowska)

\begin{tabular}{|c|c|c|c|c|c|}
\hline $\begin{array}{l}\text { SH name proposed in UNITE for the sequences } \\
\text { received in culture based approach (SH number) }\end{array}$ & $\begin{array}{l}\text { number } \\
\text { of } \\
\text { isolates }\end{array}$ & $\begin{array}{l}\text { SH name proposed in UNITE for the sequences } \\
\text { received in cloning based approach (SH number) }\end{array}$ & $\begin{array}{l}\text { GB number of } \\
\text { closest } \\
\text { sequence }\end{array}$ & $\begin{array}{l}\% \text { of } \\
\text { similarity }\end{array}$ & $\begin{array}{l}\% \text { of } \\
\text { clones }\end{array}$ \\
\hline Leiosphaerella lycopodina (SH230356.06FU) & 2 & Leiosphaerella lycopodina (SH230356.06FU) & JF440975 & $99 \%$ & $22 \%$ \\
\hline \multirow[t]{6}{*}{ Mycosphaerella sp. (SH195177.06FU) } & 4 & Mycosphaerella sp. (SH195177.06FU) & EU167581 & $94 \%$ & $22 \%$ \\
\hline & & Pseudocercosporella sp. (SH195098.06FU) & AY805600 & $100 \%$ & $6 \%$ \\
\hline & & Botryosphaeria corticis (SH206853.06FU) & HQ529751 & $99 \%$ & $21 \%$ \\
\hline & & Tubeufiaceae (SH230727.06FU) & AY916453 & $99 \%$ & $6 \%$ \\
\hline & & Chalara dualis (SH208308.06FU) & EF029209 & $98 \%$ & $17 \%$ \\
\hline & & Exobasidium japonicum (SH204828.06FU) & EU692772 & $96 \%$ & $6 \%$ \\
\hline
\end{tabular}


is a common finding of studies on endophytic fungal communities (e.g. Moricca et al. 2012; Sun et al. 2012; Wearn et al. 2012 and references therein). This has led to the hypothesis that endophytism is a common phase in the life cycle of many fungal pathogens (e.g. Carroll 1988; Joshee et al. 2009; Rodriguez and Redman 1997; Schulz and Boyle 2005). Recently, Delaye et al. (2013) performed an analysis of the evolutionary stability of biotropic, necrotrophic, and endophytic lifestyles of 163 fungal strains. They suggest that while biotrophy appears to be a stable trait, asymptomatic endophytes can easily switch to necrotrophy, even at an ecological timescale. Not only is this of paramount importance for understanding the mechanisms and factors underlying alterations in fungal lifestyle, but it is also significant for studies on endophytic fungal communities. A large number of fungal species described in 19th century that often have no holotypes and are in desperate need for revision using molecular approaches. These fungi are still found on lists of fungal taxa recorded from a particular plant hosts (e.g. Farr and Rossman 2012). They were regarded as pathogens or saprotrophs, partially because molecular identification of endophytes was beyond the technical abilities at the time. Current investigations of endophytic fungal communities often exclusively apply molecular methods (Rajala et al. 2013). However a combination of these methods with culturing is best (e.g. Arnold and Lutzoni 2007). A study of the endophytic community based on molecular identification and culturing with direct observation of fungal communities on the plant material, has been successfully applied by Chaverri and Gazis (2011) and can shed more light on the question of the 'endophytic continuum'. In this way it may also be possible to link of fungal taxa described in inventories like those by Engelhardt (1987) and by Holm and Holm (1981) with sequences of unidentified endophytes generated in numerous molecular studies.

Finally, the possible roles of these endophytic fungi in interactions with lycophytes are unknown. To date, no research has been performed on whether such endophytes may in any way enhance lycophyte fitness, make them more competitive within their habitats, deter potential animal herbivores or protect from pathogenic fungi or bacteria. There is clearly much more research to be done.

Acknowledgments The study was supported by the Polish Ministry of Science and Higher Education grant NN_303 548 839. The authors wish also to acknowledge the anonymous reviewers for their helpful suggestions to the manuscript.

Open Access This article is distributed under the terms of the Creative Commons Attribution License which permits any use, distribution, and reproduction in any medium, provided the original author(s) and the source are credited.

\section{References}

Abarenkov K, Nilsson RH, Larsson KH, Alexander IJ, Eberhardt U, Erland S, Høiland K, Kjøller R, Larsson E, Pennanen T, Sen R, Taylor AFS, Tedersoo L, Ursing BM, Vrålstad T, Liimatainen K, Peintner U, Kõljalg U (2010) The UNITE database for molecular identification of fungi-recent updates and future perspectives. New Phytol 186:281-285

Abreu LM, Almeida AR, Salgado M, Pfenning LH (2010) Fungal endophytes associated with the mistletoe Phoradendron perrottettii and its host tree Tapirira guianensis. Mycol Prog 9:559-566

Altschul SF, Madden TL, Schaffer AA, Zhang J, Zhang Z, Miller W, Lipman DJ (1997) Gapped BLAST and PSI-BLAST: a new generation of protein database search programs. Nucleic Acids Res 25:3389-3402

Aptroot A (1998) A world revision of Massarina (Ascomycota). Nova Hedwigia 66:89-162

Arnold AE (2007) Understanding the diversity of foliar fungal endophytes: progress, challenges, and frontiers. Fungal Biol Rev 21:51-66

Arnold AE, Maynard Z, Gilbert GS (2001) Fungal endophytes in dicotyledonous neotropical trees: patterns of abundance and diversity. Mycol Res 105:1502-1507

Arnold AE, Maynard Z, Gilbert GS, Coley PD, Kursar TA (2000) Are tropical fungal endophytes hyperdiverse? Ecol Lett 3:267-274

Arnold AE, Lutzoni F (2007) Diversity and host range of foliar fungal endophytes: are tropical leaves biodiversity hotspots? Ecology 88: 541-549

Berch SM, Kendrick B (1982) Vesicular-arbuscular mycorrhizae of Southern Ontario ferns and fern-allies. Mycologia 74:769-776

Bruchmann H (1908) Das Prothallium von Lycopodium complanatum L. Bot Zeit 66:169-181

Budziszewska J, Szypuła W (2010) Influence of site conditions on the diversity of endophytic fungi of clubmoss species Huperzia selago (L.) Bernh. ex Schrank et Mart. Pol J Ecol 58:627-634

Budziszewska J, Szypuła W, Wilk M, Wrzosek M (2011) Paraconiothyrium babiogorense sp. nov., a new endophyte from fir club moss Huperzia selago (Huperziaceae). Mycotaxon 115:457-468

Carroll GC (1988) Fungal endophytes in stems and leaves: from latent pathogen to mutualistic symbiont. Ecology 46:692-699

Chaverri P, Gazis RO (2011) Linking ex planta fungi with their endophytic stages: Perisporiopsis, a common leaf litter and soil fungus, is a frequent endophyte of Hevea spp. and other plants. Fung Ecol 4:94-102

Chen XY, Qi YD, Wei JH, Zhang Z, Wang DL, Feng JD, Gan BC (2011) Molecular identification of endophytic fungi from medicinal plant Huperzia serrata based on rDNA ITS analysis. World J Microbiol Biotechnol 27:495-503

Colwell RK (2006) EstimateS: Statistical estimation of species richness and shared species from samples. Version 8. User's Guide and application published at: http://purl.oclc.org/estimates. Department of Ecology and Evolutionary Biology, University of Connecticut, Storrs, USA

Crous PW, Wingfield MJ, Guarro J, Cheewangkoon R, van der Bank M, Swart WJ, Stchigel AM, Cano-Lira JF, Roux J, Madrid H, Damm U, Wood AR, Shuttleworth LA, Hodges CS, Munster M, de Jesús Yáñez-Morales M, Zúñiga-Estrada L, Cruywagen EM, de Hoog GS, Silvera C, Najafzadeh J, Davison EM, Davison PJN, Barrett MD, Barrett RL, Manamgoda DS, Minnis AM, Kleczewski NM, Flory SL, Castlebury LA, Clay K, Hyde KD, Maússe-Sitoe SND, Chen S, Lechat C, Hairaud M, Lesage-Meessen L, Pawlowska J, Wilk M, Sliwinska-Wyrzychowska A, Metrak M, Wrzosek M, Pavlic-Zupanc D, Maleme HM, Slippers B, Mac Cormack WP, Archuby DI, Grünwald NJ, Tellería MT, Dueñas M, Martín MP, Marincowitz S, de Beer ZW, Perez CA, Gené J, Marin-Felix Y, Groenewald JZ (2013) Fungal planet description sheets: 154-213. Persoonia 31:188-296

Delaye L, Garcia-Guzman G, Heil M (2013) Endophytes versus biotrophic and necrotrophic pathogens - are fungal lifestyles evolutionarily stable traits? Fungal Divers 60:125-135 
Damm U, Verkley GJM, Crous PW, Fourie PH, Haegi A, Riccioni L (2008) Novel Paraconiothyrium species on stone fruit trees and other woody hosts. Persoonia 20:9-17

Davis EC, Franklin JB, Shaw AJ, Vilgalys R (2003) Endophytic Xylaria (Xylariaceae) among liverworts and angiosperms: phylogenetics, distribution, and symbiosis. Am J Bot 90:1661-1667

Davis EC, Shaw AJ (2008) Biogeographic and phylogenetic patterns in diversity of liverwort-associated endophytes. Am J Bot 95:914-924

Domsch KH, Gams W, Anderson TH (1993) Compendium of soil fungi. Vol. I \& II; IHW-Verlag. Eching, Germany, p 859 and p. 405

Ek-Ramos MJ, Zhou W, Valencia CU, Antwi JB, Kalns LL, Morgan GD, Kerns DL, Sword GA (2013) Spatial and temporal variation in fungal endophyte communities isolated from cultivated cotton (Gossypium hirsutum). PLoS One 8:e66049

Engelhardt K (1987) Perfekte Ascomyceten an zwei Bärlapparten des Lichtenfelser Forstes. In: Band A (ed) Pilzflora Nordwestoberfrankens. Weidhausen bei Coburg 11, pp 33-38

Farr DF, Rossman AY (2012) Fungal Databases, Systematic Mycology and Microbiology Laboratory, ARS, USDA. http://nt.ars-grin.gov/ fungaldatabases/; Accessed 4 Sept 2013

Fisher RA, Corbet AS, Williams CB (1943) The relation between the number of species and the number of individuals in a random sample of an animal population. J Anim Ecol 12:42-58

Freeberg JA (1962) Lycopodium prothalli and their endophytic fungi as studied in vitro. Am J Bot 49:530-535

Hagen A (1950) Notes on Arctic fungi. II. Fungi collected by Dr P. F. Scholander on the Swedisch-Norwegian Arctic expedition 1931. Nor Polarinst Skr 93:12-25

Hall TA (1999) BioEdit: a user-friendly biological sequence alignment editor and analysis program for Windows 95/98/NT. Nucl Acids Symp Ser 41:95-98

Hammer $\breve{R}$, Harper DAT, Ryan PD (2001) PAST: paleontological statistics software package for education and data analysis. Palaeontol Electron 4:1-9

Hata K, Futai K (1995) Endophytic fungi associated with healthy pine needles and needles infested by the pine needle gall midge, Thecodiplosis japonensis. Can J Bot 73:384-390

Higgins LK, Arnold AE, Miadlikowska J, Sarvate SD, Lutzoni F (2007) Phylogenetic relationships, host affinity, and geographic structure of boreal and arctic endophytes from three major plant lineages. Mol Phylogenet Evol 42:543-555

Higgins HL, Coley PD, Kursar TA, Arnold AE (2011) Culturing and direct PCR suggest prevalent host generalism among diverse fungal endophytes of tropical forest grasses. Mycologia 103:247-260

Holm K, Holm L (1984) A contribution to the mycoflora of Iceland. Acta Bot Is1 7:3-11

Holm L, Holm K (1981) Ascomycetes on Nordic Lycopods. Karstenia 21:57-72

Jaccard P (1912) The distribution of the flora in the alpine zone. New Phytol 11:37-50

Jaklitsch WM, Samuels GJ, Dodd SL, Lu B-S, Druzhinina IS (2006) Hypocrea rufa/Trichoderma viride: a reassessment, and description of five closely related species with and without warted conidia. Stud Mycol 55:135-177

Jaklitsch WM, Voglmayr H (2012) Phylogenetic relationships of five genera of Xylariales and Rosasphaeria gen. nov. (Hypocreales). Fungal Divers 52:75-98

Joshee S, Paulus BC, Park D, Johnston PR (2009) Diversity and distribution of fungal foliar endophytes in New Zealand Podocarpaceae. Mycol Res 113:1003-1015

Kessler M, Jonas R, Cicuzza D, Kluge J, Piątek K, Naks P, Lehnert M (2010a) A survey of the mycorrhization of Southeast Asian ferns and lycophytes. Plant Biol 12:788-793

Kessler M, Jonas R, Strasberg D, Lehnert M (2010b) Mycorrhizal colonizations of ferns and lycophytes on the island of La Reunion in relation to nutrient availability. Basic Appl Ecol 11:329-336
Kõjalg U, Larsson K-H, Abarenkov K, Nilsson RH, Alexander IJ, Eberhardt U, Erland S, Høiland K, Kjøller R, Larsson E, Pennanen T, Sen R, Taylor AFS, Tedersoo L, Vrålstad T, Ursing BM (2005) UNITE: a database providing web-based methods for the molecular identification of ectomycorrhizal fungi. New Phytol 166:1063-1068

Kõljalg U, Nilsson RH, Abarenkov K, Tedersoo L, Taylor AFS, Bahram M, Bates ST, Bruns TD, Bengtsson-Palme J, Callaghan TM, Douglas B, Drenkhan T, Eberhardt U, Dueñas M, Grebenc T, Griffith GW, Hartmann M, Kirk PM, Kohout P, Larsson E, Lindahl BD, Lücking R, Martín MP, Matheny PB, Nguyen NH, Niskanen T, Oja J, Peay KG, Peintner U, Peterson M, Põldmaa K, Saag L, Saar I, Schüßler A, Scott JA, Senés C, Smith ME, Suija A, Taylor DL, Telleria MT, Weiß M, Larsson K-H (2013) Towards a unified paradigm for sequence-based identification of fungi. Mol Ecol 22:5271-5277

Kruskal W, Wallis WA (1952) Use of ranks in one-criterion variance analysis. J Am Stat Assoc 47:583-621

Leake JR, Cameron DD, Beerling DJ (2008) Fungal fidelity in the mycoheterotroph-to-autotroph life cycle of Lycopodiaceae: a case of parental nurture? New Phytol 177:572-576

Lee J-K, Eom A-H, Lee S-S, Lee CH (2001) Mycorrhizal symbioses found in roots of fern and its relatives in Korea. J Plant Biol 44:81-86

Leuchtmann A (1984) Über Phaeosphaeria Miyake und andere bitunicate Ascomyceten mit mehrfach querseptierten Ascosporen. Sydowia 37:75-194

Moricca S, Ginetti B, Ragazzi A (2012) Species- and organ-specificity in endophytes colonizing healthy and declining Mediterranean oaks. Phytopatologia Mediterr 51:587-598

Muthukumar T, Prabha K (2013) Arbuscular mycorrhizal and septate endophyte fungal associations in lycophytes and ferns of south India. Symbiosis 59:15-33

Pielou EC (1966) The measurement of diversity in different types of biological collections. J Theor Biol 13:131-144

Rajala T, Velmala SM, Tuomivirta T, Haapanen M, Müller M, Pennanen $\mathrm{T}$ (2013) Endophyte communities vary in the needles of Norway spruce clones. Fungal Biol 117:182-190

Ranker TA, Haufler CH (2008) Biology and evolution of Ferns and Lycophytes. Cambridge University Press, Cambridge

Read DJ, Duckett JG, Francis R, Ligrone R, Russell A (2000) Symbiotic fungal associations in 'lower' plants. Phil Trans R Soc Lond B 355: $815-831$

Remy W, Taylor TN, Hass H, Kerp H (1994) Four hundred-million-yearold vesicular arbuscular mycorrhizae. Proc Natl Acad Sci U S A 91: 11841-11843

Rodriguez RJ, Redman RS (1997) Fungal life-styles and ecosystem dynamics: biological aspects of plant pathogens, plant endophytes and saprophytes. Adv Bot Res 24:170-193

Rodriguez RJ, White JF Jr, Arnold AE, Redman RS (2009) Fungal endophytes: diversity and functional roles. New Phytol 182:314-330

Saccardo PA (1889) Mycetes Sibirici. Bull Soc R Bot Belg 28:77-120

Saikkonen K, Faeth SH, Helander M, Sullivan TJ (1998) Fungal endophytes: a continuum of interactions with host plants. Annu Rev Ecol Syst 29:319-343

Samson RA, Hoekstra ES, Frisvad JC (2004) Introduction to food- and airborne fungi (7th Ed.). Centraalbureau voor Schimmelcultures, Utrecht, The Netherlands. 389 p

Schmid E, Oberwinkler F (1993) Mycorrhiza-like interaction between the achlorophyllous gametophyte of Lycopodium clavatum L. and its fungal endophyte studied by light and electron microscopy. New Phytol 124:69-81

Shannon CE (1948) A mathematical theory of communication. Bell Syst Tech J 27:379-423

Stone JK, Polishook JD, White JRJ (2004) Endophytic fungi. In: Mueller G, Bills GF, Foster MS (eds) Biodiversity of fungi: Inventory and monitoring methods. Elsevier, Burlington, pp 241-270 
Schulz B, Boyle C (2005) The endophytic continuum. Mycol Res 109:661-686

Sun X, Ding Q, Hyde KD, Guo LD (2012) Community structure and preference of endophytic fungi of three woody plants in a mixed forest. Fungal Ecol 5:624-632

Taylor TN, Hass H, Kerp H (1999) The oldest fossil ascomycetes. Nature 399:648

Taylor TN, Hass H, Kerp H, Krings M, Hanlin RT (2004) Perithecial ascomycetes from the $400 \mathrm{MaBP}$ Rhynie Chert: an example of ancestral polymorphism. Mycologia 96:1427-1443

U'Ren JM, Lutzoni F, Miadlikowska J, Laetsch AD, Arnold AE (2012) Host- and geographic structure of endophytic and endolichenic fungal communities at a continental scale. Am J Bot 99:898-914

Wang B, Qiu Y-L (2006) Phylogenetic distribution and evolution of mycorrhizas in land plants. Mycorrhiza 16:299-363

Wang Y, Zeng QG, Zhang ZB, Yan RM, Wang LY, Zhu D (2011) Isolation and characterization of endophytic huperzine Aproducing fungi from Huperzia serrata. J Ind Microbiol Biotechnol 38:1267-1278

Watanabe T (2002) Pictorial atlas of soil and seed fungi: morphologies of cultured fungi and key to species. CRC Press, Boca Raton, p 489
Wearn JA, Sutton BC, Morley NJ, Gange AC (2012) Species and organ specificity of fungal endophytes in herbaceous grassland plants. $\mathrm{J}$ Ecol 100:1085-1092

White TJ, Bruns T, Lee S, Taylor J (1990) Amplification and direct sequencing of fungal ribosomal RNA genes for phylogenetics. In: Innis MA, Gelfland DH, Sninsky JJ, White TJ (eds) PCR protocols: A guide to methods and applications. Academic, New York

Whittier DP (1977) Gametophytes of Lycopodium obscurum grown in axenic culture. Can J Bot 55:563-567

Wilson D (1995) Endophytes - the evolution of the term, a clarification of its use and definition. Oikos 73:274-276

Xiang JG, Shan WG, Liang DE, Ying YM, Gan LS, Wang JW, Zhan ZJ (2013) N-gearing Furanone derivatives from an endophytic fungus in Huperzia serrata. Helv Chim Acta 96:997-1003

Zhang ZB, Zeng QG, Yan RM, Wang Y, Zou ZR, Zhu D (2011) Endophytic fungus Cladosporium cladosporioides LF70 from Huperzia serrata produces Huperzine A. World J Microbiol Biotechnol 27:479-486

Zhou D, Hyde KD (2001) Host-specificity, host-exclusivity and hostrecurrence in saprobic fungi. Mycol Res 105:1449-1457

Zhu D, Wang J, Zeng Q, Zhang Z, Yan R (2010) A novel endophytic Huperzine A-producing fungus, Shiraia sp. Slf14, isolated from Huperzia serrata. J Appl Microbiol 109:1469-1478 